\title{
Russian Transition from the Traditional to the Industrial Society
}

\author{
${ }^{1}$ Yuriy D. Korobkov, ${ }^{2}$ Svetlana S. Velikanova, ${ }^{3}$ Alexey G. Ivanov, ${ }^{4}$ Natalia V. Kozhushkova, \\ ${ }^{5}$ Irina I. Sunagatullina, ${ }^{*}$ Oksana P. Chernykh \\ 1,2,3,4,5 Nosov Magnitogorsk State Technical University, 38 Lenin Avenue, 455000, Chelyabinsk Region, \\ Magnitogorsk, Russia \\ ${ }^{6}$ Moscow University of Finance and Law MFUA, 17/1 Serpukhov Val Str., 115191, Moscow, Russia \\ Email:*cherry-100@yandex.ru
}

Received: $16^{\text {th }}$ May 2018, Accepted: 04 ${ }^{\text {th }}$ June 2018, Published: $30^{\text {th }}$ June 2018

\begin{abstract}
The relations of labor and capital in Russia were entangled in patriarchal remnants and their compliance with the standards of the industrial era was becoming one of the major social problems, from the solution of which the industrial development of the country depended in many respects. Considering the significance of the Urals in Russian economy, the analysis of the local bourgeoisie position concerning the working issue solution is of an undoubted interest. It was characterized by the combination of liberal approaches with the conservative views of mining workers, which, considering local specifics, regarded the solution of the land issue, the restriction of factory inspection functions and the removal of the state administration interference in the relations between the workers and the bourgeoisie as the main means of the working issue settling.
\end{abstract}

Keywords: Bourgeoisie, Workers, The Urals, Factory Legislation, Revolution.

\section{Introduction \\ Introduction to the problem}

The competitive or the cooperative nature of labor and capital interaction is a timeless factor of production relations in the industrial and postindustrial era. The development of a civilized type of relations between workers and employers largely depends on its competent decision, which, as the world practice shows, significantly influences the effectiveness of the country social and economic development and the stability of society.

\section{Problem relevance}

At the end of the XIXth century Russia was at the stage of transition from the traditional to the industrial society. The modern Russian society is in the same transitional state. With this in mind, the study of intergroup interaction peculiarities between bourgeoisie and the working class in the early 20th century is not only of scientific, but also of practicalpolitical interest. The study of this subject matter complex using the regional example of the mining
Ural and its comparison with the current situation will make it possible to identify long-term risk factors and minimize their negative impact on the socio-economic development of the country.

\section{Problem study}

The study of the Ural bourgeoisie position on the working issue and its influence on the nature of intergroup interaction from different ideological and theoretical positions was carried out at all stages of Russian historiography, however, this problem was not raised as a special one, and during its prerevolutionary stage its separate plots were considered in the generalizing works by V.D. Belov (Belov V.D., 1910), A.N. Mitinsky (Mitinsky A.N., 1909), I.Kh. Ozerov (Ozerov I.Kh., 1910) on the mining industry of the region.

The feature of Soviet historiography was the consideration of this problematic from the standpoint of the class approach and, as a consequence, an unambiguously negative assessment of the Ural bourgeoisie position on the labor issue. Secondly, unlike the works of general Russian character on the Ural material, this subject matter was not an independent object of study, and its separate subjects were considered in the generalizing studies by M.P. Vyatkin (Vyatkin M.P., 1965), Yu.A. Buranov (Buranov Yu.A. 1982) and D.V. Gavrilov (Gavrilov D.V., 1985).

At the post-Soviet stage, the number of papers has increased on this subject and the evaluation quality of bourgeoisie theory and practice on the working issue has been changed. They become more objective and reasonable. In particular, its positive role is marked in the modernization of the Urals industry and the working issue solution. Along with the generalizing research by I.V. Narsky (Narsky I.V., 1995), N.N. Alevras (Alevras N.N., 1996), Yu.D. Korobkov (Korobkov Yu.D., 2010) there are also special works (Druzin M.V., 2013). At the same time, the consideration of the Ural bourgeoisie position as the factor of inter-group interaction and as an independent problem was not raised. 


\section{Hypotheses}

Taking into account the prevalence of the patriarchalsubordinate nature of intergroup interaction in the Urals industry, the position of the local bourgeoisie and the practice of its relations with workers was one of the main factors of production relations in the mining Ural region and it largely preserved the "original system" of the mining industry of the region.

\section{Methods}

The main methods of this article creation were historical and genetic one, which allows to trace the impact of Russia capitalist modernization on the changes in the position of the Ural bourgeoisie towards the local proletariat, the historical comparative method, which makes it possible to consider these changes in a comparative context, the historical typology method, which allows to reveal the main categories of changes in the attitudes and behavioral stereotypes of the Urals industry "commanders". The consideration of the Ural bourgeoisie view evolution in the broader context of the capitalist transformation of Russia and taking into account the diversity of the corresponding changes predetermined the importance of the historical and systemic method.

\section{Results \& Discussion}

During the development of capitalism in Russia and the development of social-economic relations inherent in it, the rise of the social movement the authorities faced with the problem of the working issue civilized solution and, above all, the development of an appropriate legal framework for the relationship between labor and capital. The revolutionary events at the beginning of the twentieth century showed this with a particular acuity. Therefore, the adoption of civilized factory and plant legislation in Russia became one of the most urgent issues of the country internal development. Social calm, progress and prosperity of the country largely depended on its competent decision in many ways.

This was clearly recognized both in government circles and in the field. The position of the Ural managers, who had their own point of view on a number of issues, different from the "view from above" is of undoubted interest. These differences resulted, first of all, from their enormous influence on the relationship between labor and capital, an original structure of the mining industry of the Urals, which remained practically unchanged up to the beginning of the 20th century. First of all, the thing is about such a characteristic trait as commitments, according to which, the Urals mining workers were obliged to provide all workers with work by law, and if there was not enough work for everyone during the population and technical progress increase - they were obliged to provide them with the means of existence.

The consequence of this unique situation was the paternalistic basis of labor and capital relations at the Ural enterprises. The factory administration was convinced that the workers had no "specially" hostile "attitude to the plant administrations" (RSHA. F.48. Inv.1, C. 230. Sh. 97). The development of the labor movement was associated with the agitation of the alien workers and social democrats, the terror of the "active" minority of workers in relation to the "quiet" majority, the influence of all-Russian situation, and the requirements of "justice and humanity towards the lower strata of the population, which increased much more than the improvement of economic and social conditions of their life" (RSHA F.48., Inv.1, C.230, Sh.13). It is not by chance that "the first and largest riots occurred in those factories where the economic situation of the workers was the best one" (RSHA, F.74. Inv.1., C.316, Sh.9), but with a significant number of newcomers.

For their part, the workers considered themselves as "completely secured from the possibility of losing their jobs", they were sure that "the established factory order will not be changed for centuries" (RSHA F.51, Inv.1, C.230, Sh.114), which developed the moods of social dependency and consumer attitudes toward factory affairs.

At the same time, the relations of the "social partnership" were rather contradictory, complicated and complex. Their typical manifestation was mutual distrust, "arrow" consciousness, the predominance of the psychological stereotype "we and them" in intergroup relations and private interests over general factory ones. The workers were characterized by the accusation of the administration in poor organization and low productivity of factory works, the requirement of participation "in hiring and quotations together with the administration", which became the leading one in the claims of workers during 1917.

The miners considered that the dissatisfaction of the workers was usually caused either by inevitable production conflicts, or by an excessive demand of the administration, which turned into arbitrariness sometimes, by its inattention to their needs. Although businessmen blamed the mainly the workers, accusing them of negligence towards their duties, the desire to harm a plant, in all kinds of deceptions to justify bad, improper work, and one of the main causes of social conflicts was the "bad character of people in general" and laziness and bad faith among the workers in general, and in the Urals in particular (RSHA, F. 48. Inv.1. C. 234. Sh.5). The causes of discontent were eliminated by mutual agreement of the parties easily. Therefore, in the opinion of the mining workers, only a small minority of workers 
responded consciously to the appeals of agitators. The "quiet" majority was neutral, or opposed strikes.

According to the factory administration, the revolution gave nothing to the workers. Despite the widespread growth of wages, the satisfaction of workers' economic demands in most cases, their financial situation from the point of view of the district engineers of the Ural mountain districts during the years of the revolution changed little, primarily because the growth in wages was compensated by the growth of prices for consumer goods. Besides, the result of an 8-hour working day introduction is the decrease of shift number and the contingent of workers has increased, which, in turn, has adversely affected the working budget.

Miners have emphasized the negative impact of the revolution on the state of the Urals industry. It manifested itself in the fall of labor discipline, the increase of absenteeism number and, correspondingly, the decline of labor productivity under the influence of the labor movement politicization, constant meetings and the meetings of workers on the issues of the liberation struggle. This slowed down the work and led to their appreciation. The revolution awakened the destructive motives in the psychology of the workers, provoked a powerful surge of anarchic actions, manifested primarily in the seizures of land and factories, in the terror against the factory administration. The meeting of the Ural industrialists with the Perm governor on January 18, 1906, noted that the growth of anarchist sentiments was strengthened under the influence of the Manifesto on October 17. The freedoms granted by it were misinterpreted by the Ural workers. "The population, under the influence of agitation, lost the faith in their claims, considering all laws that protect land, forestry, and factory ownership are abolished" (RSHA, F.48., Inv.1, C.234., Sh.68). Besides, as the head of the Izhevsk garrison Sevastyanov noted, "some of the workers have a tendency to think that the various rules and regulations that existed before the Manifesto, lose their force with its adoption and the factory bosses have no right to fire workers ..." (The Highest Rise of the Revolution of 1905-07, 1955).

In the years of the revolution, the moral standards of the workers began to sway, their sense of duty was shaken, which led to the growth of an "unstable nervous state." The growth of drunkenness became one of the consequences of the "moral threshold" reduction among the mining population. According to the manager of Verkh-Isetsky plant, wine consumption increased by 1.5 times on the average. The Ural industrialists had their own strategy and tactics concerning the situation stabilization and "the calming down" of workers. They assessed the policy of the tsarist government "forceful pressure" negatively with regard to the labor movement. Assessing the situation reasonably that existed then at the Ural plants, they spoke out against the use of the Cossacks in December 1905 under the conditions of socialist propaganda dominance and the "terror of the socialists" in the Urals, and they offered to wait when "the quiet majority" was tired of it, and it will make a restraining influence on the masses. A month later, the head of the Bureau of the Council of Mining Industrialist Congresses, V.V. Mamontov noted that "the declaring of emergency protection for all plants may damage the cause of calming the population in many places" (RSHA, F.48, Inv.1, C. 234, Sh.68). He proceeded from the fact that the revolutionary parties almost lost their influence among the masses, and a "clear reaction" towards them began among the population, and therefore such a move by the government could provide them with the halo of the great martyrs once again.

Entrepreneurs considered "the upbringing and the education of the population in the spirit of legality and respect for the rights of others", the raising of the cultural level of masses, progressive factory legislation, with the provision of association freedom for workers, the introduction of political freedoms and the liberalization of the existing regime as the promising measures. An interesting material on the methods of the working issue solution, proposed by the Urals managers, was given to the meeting of representatives of 9 mining districts in April 1905 in Yekaterinburg.

Formulating their program on the working issue, the Ural industrialists proceeded from both a general assessment of the working-class movement and from its regional characteristics. The essence of a worker, in his opinion, consisted in striving for a better future, achieved by natural means. Any interference, either in the form of legislative or administrative restrictions, or in the form of encouragement from political parties, could lead to public order shocks.

The specificity of local workers was pointed out among the Uralic features first of all. Proceeding from the assessment of a Ural worker as an exceptional example of the "a factory worker, a rural commoner, a householder, a landowner and mostly a farmer", who was bound by a "whole cycle of historical relations" with the mining industry, the absence of a free labor market at the Ural plants, the use of the indigenous population almost exclusively during plant works, the fine knowledge of their interests by the Ural workers and their ability to defend them independently (Korobkov Y., Velikanova S., Arakcheeva Z., Kozhushkova N., Chernykh O., Antipanova N., 2017), the participants of the meeting evaluated the possibilities of the factory legislation designed by the Ministry of Trade and Industry critically. They 
believed that all factory laws are oriented toward "a purely factory way in other areas" and do not reflect the Urals specificity. In accordance with this, the main means of the working problem solution in the Urals was considered by entrepreneurs as "the resolution of the entire Ural land disorder" that threatened the Ural population with the final loss of any concept of landed property.

At the same time, the task was to change "the policy of the work issue by the provision of some positive help for workers, with a possible restriction of extensive administrative, governmental interference in relation to industrialists and workers and the provision of the necessary freedom of action for both of them" (RSHA F.48. Inv.1, C.230., Sh.139).

Proceeding from this, the Ural managers advocated the abolition of criminal prosecution for economic strikes, which were one of the main means of worker interest protection. Besides, the prohibition to defend worker rights, to impose their conditions on an entrepreneur increased, in their opinion, the number of spontaneous acts, riots, pogroms, violence by workers and destabilized both the development of the economy and the public situation in the country.

The state and the perspectives of the trade union movement, which became more active under the influence of the revolution, were viewed skeptically by industrialists. The fact is that the trade union construction with some success under the influence of political agitation in 1905, subsequently stopped, although the plant administrations declared their readiness to help the workers. Entrepreneurs saw the low cultural level of workers as the main reason for the failure in the organization of trade unions. As soon as the last ones found out that their activities are connected with self-taxation in the statutes of the existing unions, "disputes and disagreements arose, and the matter ended with nothing" (RSHA, F. 37. Inv., 58. C. 361. Sh. 53).

Aiming the government to create such an economic system, "in which the working class can reach a certain level of cultural existence," the Ural experts pointed to the close relationship of the proposed reforms with the fundamental changes in many areas of public life. First of all, they noted the need to introduce political freedoms, the inviolability of an individual and a place of residence. The settlement of disputes between workers and masters presupposed, in its turn, the creation of an independent court, based only on the exact observance of the law, developed with the participation of interested parties and free from any external pressure.

The meeting also addressed issues of labor protection, wage increase, and a working day reduction. The plant owners recognized the harmful regulation of working time and considered the reasonable solution of labor conflicts in the Urals is the mutual agreement of the parties concerned, subject to the freedom of strikes and assemblies. Accordingly, the functions of the factory inspection were limited, which should not interfere with the internal regulations at the enterprises and could only be engaged in the "supervision" with the bringing to justice. The intervention of the state administration in the relations between workers and factory management should be eliminated. Workers' organizations must be of a guild character with a complete freedom, without limitation of elected representative number.

The meeting differentiated the strikes into unauthorized and sanctioned ones and proposed to shorten the period of warning from 3 weeks to 3 days. An "unannounced" strike was recognized as "a spontaneous force that suspends the operation of an employment contract." Thus, the administration was looking for a way to dismiss workers for the participation in a strike. The meeting reacted negatively to the possibility of worker participation in the determination of wages and prices, believing that the existence of shop organizations and the freedom of strikes is sufficient for the workers.

The Ural mining companies believed that economic growth is impossible without "broad intellectual development of workers". The main means of this problem solution was the expansion of general and technical school network. They also pointed out the need to improve the quality of education. The main means of this problem solution was the orientation of schooling to "the preparation for the upcoming practical work". An important place in the expansion of worker horizons must be occupied by the increase of extracurricular institution number: libraries, reading rooms, general education courses.

\section{Conclusions}

Obviously, the position of the Ural bourgeoisie on the working issue is quite contradictory. On the one hand, it took into account the peculiarities of its region development, the psychology of the local population, and proposed those recipes to solve the working issue that took into account local specifics. This, in its turn, it contributed considerably to the preservation of the historically formed type of production. At the same time, it was under the considerable influence of the liberal tradition. In general, it exaggerated the influence of the patriarchal component of intergroup relations and was utopian in its own way, which was really confirmed by the events of the Russian revolutions of the early 20 th century, when mass antibourgeois sentiments became the leading trend in the group consciousness of the social lower classes, and the increase of violence towards it exceeded general Russian parameters in the Urals. 


\section{Conflict of Interest}

The authors argue that the presented data do not contain a conflict of interest.

\section{References}

[1] Alevras N.N. Agrarian policy of the government in the mining Urals during the early XXth century. Chelyabinsk, 1996. 212 p. [in Russian].

[2] Belov V.D. The crisis of the Ural mining plants. SPB., 1910. 301 p. [in Russian].

[3] Buranov Yu.A. Joint-stock company creation in the mining industry of the Urals. M., 1982. 214 p. [in Russian].

[4] The highest rise of the revolution of 1905 1907. Armed uprising. P.2. M., 1955. 1285 p.

[5] Vyatkin M.P. Mining Urals in 1900-1917. M.; L., 1965. 398 p. [in Russian].

[6] Gavrilov D.V. Working class of the Urals during the period of pre-monopoly capitalism. 1861-1900. M., 1985. 302 p. [in Russian].

[7] Drusin M.V. Ural miners and power in the late XIX - early XX century. The abstract of the dis .... by the cand. of hist. sciences. SPb., 2013. 27 p. [in Russian].

[8] Korobkov Yu.D. Social shape of the mining workers of the Urals during the post-reform period: the features of formation and definition // Problems of Russian history. 2010. №1 (10). pp. 5-17 [in Russian].

[9] Korobkov Y., Velikanova S., Arakcheeva Z., Kozhushkova N., Chernykh O., Antipanova $\mathrm{N}$. Social and economic adaptation of mining workers of the Urals region in the late of the XIX - the beginning of the XX century. The Turkish Online Journal of Design, Art and Communication TOJDAC April 2017 Special Edition Submit Date: 02.02.2017, Acceptance Date: 02.03.2017, DOI NO: 10.7456/1070ASE/148. Copyright (C) The Turkish Online Journal of Design, Art and Communication, pp. 1219-1226.

[10] Mitinsky A.N. Mining Urals. St. Petersburg, 1909. 244 p. [in Russian].
[11] Narsky I.V. Russian provincial party membership. Political associations in the Urals until 1917. On the issue of the democratic tradition in Russia. Chelyabinsk, 1995. Part 2. 366 p. [in Russian].

[12] Ozerov I.Kh. Mountain plants of the Urals. M., 1910. 253 p. [in Russian].

[13] RSHA F.48. Inv.1. C. 230. Sh. 139.

[14] RSHA F.48. Inv.1. C. 234. Sh. 68.

[15] RSHA. F. 37. Inv. 58. C. 361. Sh. 53.

[16] RSHA. F. 48. Inv. 1. C. 234. Sh. 5.

[17] RSHA. F. 48. Inv. 1. C. 234. Sh. 68.

[18] RSHA. F. 74. Inv. 1. C. 316. Sh. 9.

[19] RSHA. F,51. Inv.1. C.230. Sh.114.

[20] RSHA. F.48. Inv. 1 . C.230. Sh.13.

[21] RSHA. F.48. Inv.1. C,230. Sh. 97. 